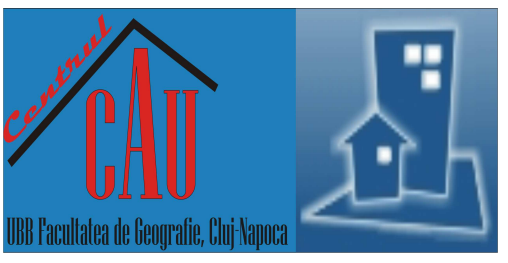

\title{
Banking Sector and Economy of CEE Countries: Development Features and Correlation
}

\author{
Iurii UMANTSIV', Olena ISHCHENKO' \\ 1 Kyiv National University of Trade and Economics, Faculty of Economics, Management and Psychology, Department of Economic \\ Theory and Competition Policy, Kyiv, UKRAINE \\ E-mail:markov8@ukr.net,prepodsha4u@gmail.com \\ DOI: 10.24193/JSSP.2017.1.05 \\ https://doi.org/10.24193/JSSP.2017.1.05
}

K e y w o r d s: economy of CEE country, banking system, financial sector, role of banks, correlation between GDP and bank investments, EU operational programs, CEE countries, banking sector development

\begin{abstract}
A B S T RA C T
This research focuses on the analysis of current trends in the banking sector of Central and Eastern Europe (CEE), and on its role in the development of the economy. This region is represented by countries situated at different levels of development and types of economic system. The following countries are analyzed: Bulgaria, Poland, Romania, the Republic of Belarus and Ukraine. The article starts with a general description of the economy of each of the five countries listed above, followed by a discussion of main trends of their development and a comparison of these states based on the status of their socioeconomic development. The study will also examine the banking systems of each of these countries looking at the types of banks that are present on the market, capital ownership, and market share, as well as the main indicators of soundness of the banking system. The study found that there are both common features and differences in the banking sectors of the analyzed countries. We also found a correlation between the tendencies of real sector development and bank investments. Finally, our article revealed the role played by the European Union in funding the economies of analyzed countries through their operational programs.
\end{abstract}

\section{INTRODUCTION}

Financial investments play an important role in the provision of an effective and efficient economic system because they directly affect economic growth and are one of the most important indicators of economic development. The banking system that accumulates and distributes financial flows affect the state of financial markets and is the basis of investment process in the country. Indicators of economic development, such as the growth of the Gross Domestic Product (GDP) and production and the rise in real incomes of the population that are distributed in financial institutions, trade balance, budget deficit or surplus significantly affect the size and structure of bank portfolios. The processes of economic globalization and integration of financial markets have pushed for a significant reorganization and development of banking systems in many countries. The creation of the European Union, together with the establishment of a single currency and the formation of the European Central Bank, is evidence of active economic development of European countries. The reformation of the Central and Eastern European (CEE) financial sector was one of the most important and most difficult tasks in the process of economic transition from a closed system to a market economy. The CEE countries that constitute the focus of our study are characterized by different levels and rates of development. Bulgaria, Poland, and Romania have a market type of economic system while the Republic of Belarus and Ukraine are in the process of transformation from the social state economy into a market economy. One of the most important indicators 
that characterizes a country's socioeconomic development is the GDP per capita; However, recently the UN has also applied a new synthetic indicator - the human development index (HDI) that considers not only the level of GDP per capita, but also life expectancy and level of education of the population. Thus, in 2016 the analyzed countries held the following positions among 230 and 180 countries respectively, according to the above-named two indicators: Bulgaria -88 and 56 (high level), Poland - 68 and 36 (very high level), Romania - 83 and 50 (very high level), Republic of Belarus - 95 and 52 (high level), Ukraine - 149 and 84 (high level) [1], [2]. The following figure (Fig. 1) illustrates the place of CEE countries under analysis on the general map of Europe, according to the HDI. The figure also provides information about main industries, main focus for agriculture as well as the principal socioeconomic indicators for each country.
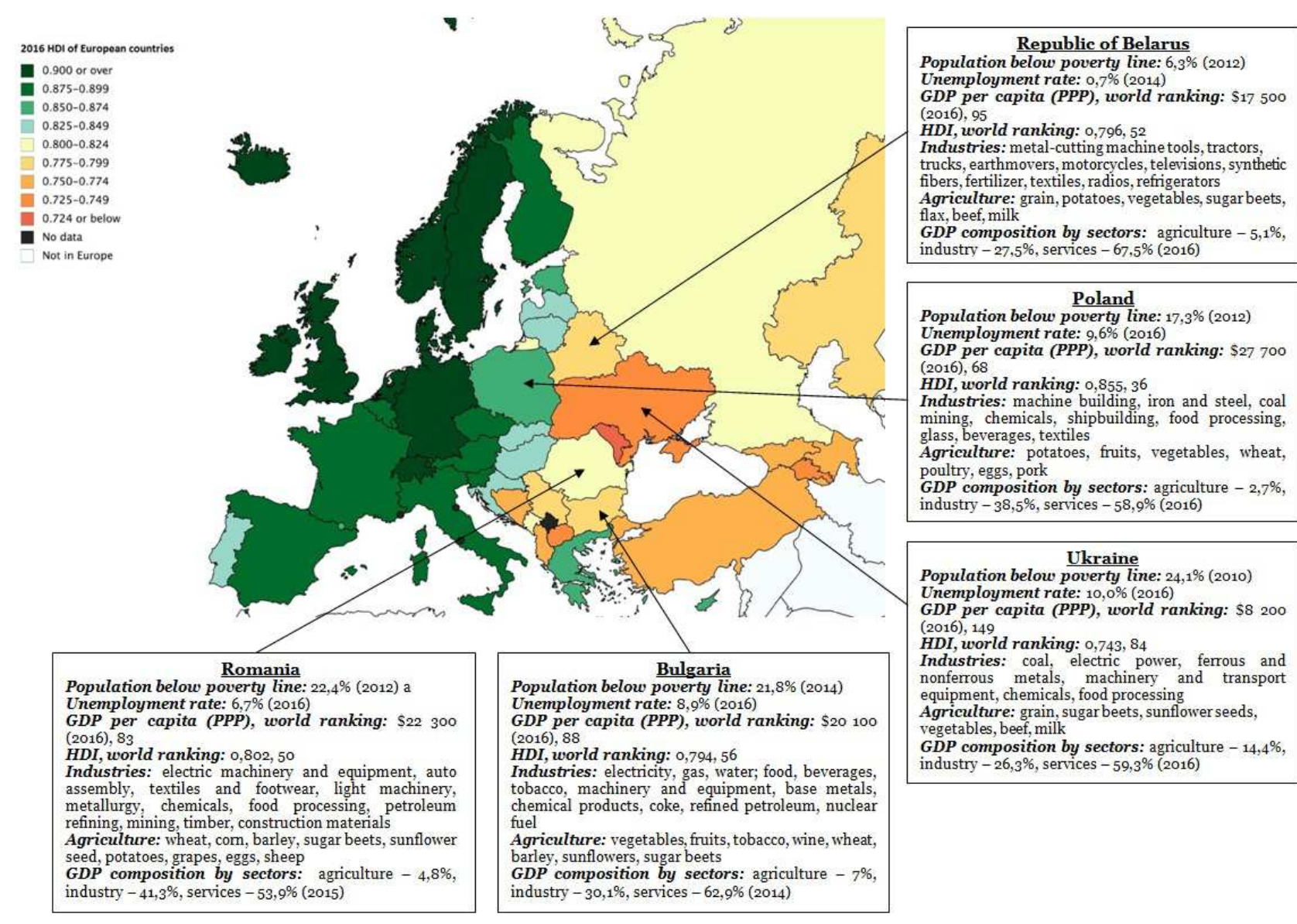

GDP composition by sectors: agniculture
industry $-27,5 \%$, services $-67,5 \%$ (2016) Poland
Population below poverty line: $17,3 \%$ (2012)
Unemployment rate: $9,6 \%(2016)$ GDP per capita (PPP), world ranking: $\$ 27700$ (2016), 68

HDI, world ranking: $0,855,36$

Industries: machine building, iron and steel, coal mining, chemicals, shipbuilding, food processing, glass, beverages, textiles Agriculture: potatoes, fruits, vegetables, wheat,

poultry, eggs, pork industry $-38,5 \%$, services $-58,9 \%$ (2016)

\begin{tabular}{|l|}
\hline Ukraine \\
Population below poverty line: $24,1 \%$ (2010) \\
Unemployment rate: $10,0 \%$ (2016) \\
GDP per capita (PPP), world ranking: $\$ 8$ 200 \\
(2016), 149 \\
HDI, world ranking: $0,743,84$ \\
Industries: coal, electric power, ferrous and \\
nonferrous metals, machinery and transport \\
equipment, chemicals, food processing \\
Agriculture: grain, sugarbeets, sunflower seeds, \\
vegetables, beef, milk \\
GDP composition by sectors: agriculture $-14,4 \%$, \\
industry $-26,3 \%$, services $-59,3 \%(2016)$
\end{tabular}

Fig. 1. The position of analyzed countries in Europe (source: Global 2016 Human Development Report. Unite Nation Development Programme. Available at: http://www.hdr.undp.org/sites/default/files/2016_human_development_report.pdf. Last accessed: June, 01, 2017; The World Factbook. Central Intelligence Agency. Available at: https://www.cia.gov/library publications/ the-world-factbook. Last accessed: June, o1, 2017).

Bulgaria is a former communist country that joined the EU in 2007. Successive governments have demonstrated a commitment to economic reforms and responsible fiscal planning but the global downturn sharply reduced domestic demand, exports, capital inflows and industrial production. GDP contracted by $5.5 \%$ in 2009 and has been slow to recover in the years since. Despite a favorable investment regime, including low, flat corporate income taxes, there still remain significant challenges. Corruption in public administration, a weak judiciary and the presence of organized crime continue to hamper the country's investment climate and economic prospects [3].

Poland has pursued a policy of economic liberalization since 1990 and Poland's economy was the only EU country to avoid a recession through the 60
2008-2009 economic downturn. Although EU membership and access to EU structural funds have provided a major boost to the economy since 2004, GDP per capita remains significantly below the EU average and the unemployment rate is now below the $E U$ average [38]. While the Polish economy has performed well over the past five years, growth slowed in 2013 and picked back up in 2014-2016. Poland's new center-right Law and Justice government plans to introduce expansionary economic policies to spur long-term growth but social spending programs are expected to lead to increased deficit spending over the medium term. Poland faces several challenges that include addressing some of the remaining deficiencies in its road and rail infrastructure, business environment, rigid labor code, commercial court 
system, burdensome tax system, especially for entrepreneurs. Additional long-term challenges include diversifying Poland's energy mix and sources of supply, strengthening investments in innovation, research and development [4].

Romania like Bulgaria joined the EU in 2007, began the transition from communism in far 1989 with a largely obsolete industrial base and a pattern of output unsuited to the country's needs. Romania's macroeconomic gains have only recently started to spur creation of a middle class and to address Romania's widespread poverty. In the aftermath of the global financial crisis, Romania signed a \$26 billion emergency assistance package from the IMF, the EU, and other international lenders but GDP contracted until 2011. Next years Romania and the IMF/EU agreed to a follow-on standby agreements (2011 - \$6.6 bln, 2013- $\$ 5.4 \mathrm{bln}$ ) to promote fiscal discipline, encourage progress on structural reforms, strengthen financial sector stability, but the progress on structural reforms has been uneven and the economy still is vulnerable to external shocks. Economic growth rebounded in 2013-2016, driven by strong industrial exports and excellent agricultural harvests and the fiscal deficit was reduced substantially. Industry outperformed other sectors of the economy in 2016. Exports remained an engine of economic growth, led by trade with the EU, which accounts for roughly $70 \%$ of Romania trade. Domestic demand was a second driver, due to the mid-2015 cut, from 24\% to 9\%, of the VAT levied upon foodstuffs. In 2015 the government of Romania succeeded in meeting its annual target for the budget deficit, the external deficit remained low, even if it rose due to increasing imports. For the first time since 1989, inflation turned into deflation, allowing for a gradual loosening of monetary policy throughout the period. An aging population, significant tax evasion, insufficient health care and an aggressive loosening of the fiscal package jeopardize the low fiscal deficit and public debt and are the economy's top vulnerabilities [5].

The economic transformations in the Republic of Belarus and Ukraine are very slow and inconsistent due to the presence in the industry of a huge number of old enterprises with backward technological processes and equipment that does not attract either a domestic or a foreign investor. Such an economy requires a lot of investments that are not available inside of these countries and are difficult to access from abroad because of imperfect legislation and unstable social development. As part of the former Soviet Union, Belarus had a relatively well-developed, though aging industrial base that now is energy inefficient and depends on subsidized Russian energy and preferential access to Russian markets. About $80 \%$ of all industry remains in the hands of the government [6].

Ukraine's dependence on Russia for energy supplies and the lack of significant structural reform have made the Ukrainian economy vulnerable to external shocks. Ukraine depends on imports to meet about three-fourths of its annual oil and natural gas requirements and $100 \%$ of its nuclear fuel needs. Ukraine's oligarch-dominated economy grew slowly from 2010 to 2013. In 2014 the international community began efforts to stabilize the Ukrainian economy, including IMF assistance package of \$14-18 billion. Ukraine has made significant progress on reforms designed to make the country a prosperous, democratic and transparent country. Russia's occupation of Crimea in March 2014 and on-going military activity in eastern Ukraine have hurt economic growth. With the loss of a major portion of Ukraine's heavy industry in Donbas, Ukraine's economy contracted by $6.6 \%$ in 2014 and by $14.3 \%$ in 2015 . Ukraine and Russia have sharply reduced trade by the end of 2015. The EU-Ukraine Deep and Comprehensive Free Trade Area started up on 1 January 2016 and is expected to help Ukraine integrate its economy with Europe by opening up markets and harmonizing regulations [7].

The research and the analysis of the banking sector position in the CEE countries, its structural and qualitative changes including national and regional peculiarities, identifying the interrelation between socioeconomic situation and the level of development of the banking sector gives the possibility to understand fatherly countries financial sector specific transformations with their different level of economic development.

\section{THEORY AND METHODOLOGY}

The research of the CEE countries banking sector's, its development peculiarities and functioning permanent models are devoted in a lot of studies of modern scientists. The world's banking systems evolution, position and role of the largest banks, their domestic and foreign branches in the world economy and international business are considered in [8]. The research results of the global financial crisis influence in 2008 on the banking systems condition of several European countries are presented by scientists in [9], [10].

Åslund A. [9] arrives at conclusions that: the Western European banks have stayed in the region; the foreign banking share has declined only marginally; the CEE bank sector is in the need of bank consolidation; the main change is that the leverage of various CEE countries evened out, being reduced in the overheated Baltics and increased in the under-banked Southeastern Europe.

In a study on the banking sector in CEE countries [10], the authors have arrived the following conclusions: the level of obligations was higher than the level of equity liabilities; foreign equity had the dominant place; the CEE banks implemented more 
restrictive and conservative credit policies, stronger classification of credit customers and other collections, increased level of equity, and maintaining and planning of their liquidity position; there was the increasing trend of credit potential in the period of 2005 to 2008 , while in 2009 it remained stagnant; there was the increasing deposit potential during the analyzed period, except for Montenegro.

Another study that has analyzed the structural, the qualitative and the quantitative changes, and the effects of financial reforms, that have taken place in the banking sector in these countries [11], concluded that, due to the favorable and simplified banks' lending terms, private sector preferred loans as the main source of external financing, that in turn led to the fact that the growth rate of the funding base of the banking sector did not match the development of real sector of economy in the CEE countries, that was mostly focused on imported goods and services. Accumulation of external financial resources in foreign currency had led to exchange rate's risks. It means that recent financial reforms have taken into account other risks of the financial system, the development of which was not correlated with the real sector development. Today the CEE countries have in general changed their attitude to other risks of the system, strengthened banking supervision and control, and put forward more requirements for the banks.

Cevik et al. (2016) examining the the banking sector in the CEE countries have shown that: the central bank communication has significant wealth effects in financial markets and tends to reduce financial market uncertainty [12]; and foreign bank ownership is associated with higher banking efficiency than in the case of domestic banks. The existing business models in European banking were investigated in [13].

Authors, researching 2542 banking groups and subsidiaries of non-European banks that account for more than 95\% of EEA and Swiss banking assets, clustered the banking sector into five categories: focused retail, diversified retail (type 1), diversified retail (type 2), wholesale and investment banks. The cost efficiency in the banking sector of European countries became a subject of studies by the authors such as Košak M. and Nurboja B. (2016) and Poloucek S. (2004) [14], [15].

In the context of the foreign experience, comparing the main indicators of the banking services' market in the CEE countries, some scientists suggest the ways of optimization of the domestic banking market functioning [16].

Recognizing the value of scientific achievements of foreign and domestic scientists and their considerable contribution to the banking activity development, it is necessary to deepen the banking systems' research of the CEE countries, paying attention to the high volatility and rapid development of foreign markets.

\section{RESULTS AND DISCUSSION}

Banks play a very important role in providing the economic growth, especially in the absence of other resources of investment, business and production financing, weak development of the stock market, insufficient government financing or its inefficient use. Considering the analysis made above regarding the socioeconomic state of researching countries with their different starting points of development, types of economies and thereafter with different approaches to the governance and opportunities to access the resources, it is important for this study to analyze the banking systems of these counties and reveal the role of banks in their development.

\subsection{Bulgarian banking system's characteristics}

The banking system of Bulgaria is concentrated, with the majority of assets in large banks with foreign ownership. At the beginning of 2017 the system includes 29 banks, six of which are owned by the residents, 17 are subsidiary banks of foreign groups, and 6 are foreign bank's branches with relatively small shares of assets in the market, such as: Alpha Bank S.A. (Greece), 1.22\%，17 ${ }^{\text {th }}$; Citibank Europe plc (Ireland), $0.95 \%, 19^{\text {th }}$; BNP Paribas S.A (France), 0.90\%, 20 ${ }^{\text {th }}$; ING Bank N.V. (Netherlands), 0.67\%, 22 ${ }^{\text {nd }}$; T. C. Ziraat Bankasi (Turkey), $0.10 \%, 27^{\text {th }}$; Isbank AG (Germany), $0.01 \%, 28^{\text {th }}[17]$. The first ten banks according to their assets ( $81.55 \%$ of total assets) represented the majority of banks with foreign capital, except First Investment Bank $\mathrm{AD}$ and Central Cooperative Bank $\mathrm{AD}$, which rank $3^{\text {rd }}$ and $8^{\text {th }}$ (Fig. 2).

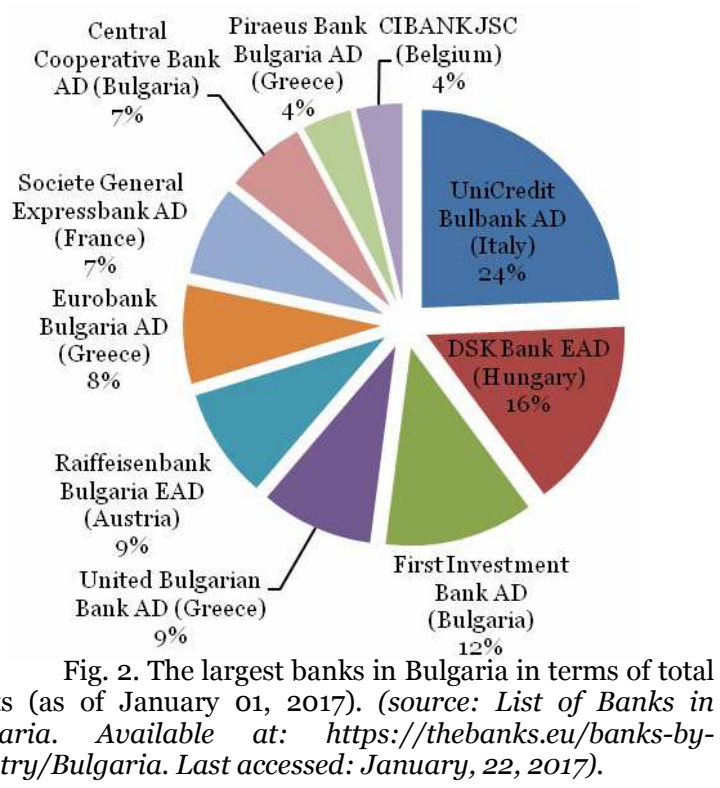

According to the BICRA methodology (Banking Industry Country Risk Assessment) designed by Standard\&Poor's, Bulgaria is included into group 7 (the lowest-risk banking systems is group 1) with economic risk scored «7» and industry risk scored «7» 
(the highest-risk is ranged as «10») [18]. According to World Economic Forum's Global Competitiveness Report 2016-2017, financial market development in Bulgaria is scored 4.1 out of maximum 7.0 and ranked 59 th out of 138 analyzed economies. Soundness of banks is scored 4.2 bringing Bulgaria into the $107^{\text {th }}$ place, and, finally, trustworthiness and confidence of financial market is scored 4.5 (49 $9^{\text {th }}$ place) [19].

Analyzing the main indicators of the banking system in the dynamics (Table 1), we can conclude that the situation is quite stable in the banking sector.

Table 1. Financial soundness indicators of banking systems.

\begin{tabular}{|c|c|c|c|c|}
\hline Indicators & Countries & 01.01.14 & 01.01.15 & 01.01.16 \\
\hline \multirow{5}{*}{$\begin{array}{l}\text { 1. Liquid } \\
\text { asset ratio, \% }\end{array}$} & Bulgaria & 23.4 & 26.1 & 31.6 \\
\hline & Poland & 21.4 & 20.6 & 20.1 \\
\hline & Romania & 56.2 & 57.4 & 54.1 \\
\hline & $\begin{array}{l}\text { Republic } \\
\text { of Belarus }\end{array}$ & 30.0 & 29.7 & 26.0 \\
\hline & Ukraine & 18.3 & 15.6 & 12.3 \\
\hline \multirow{5}{*}{$\begin{array}{l}\text { 2. Return on } \\
\text { Assets } \\
\text { (ROA), \% }\end{array}$} & Bulgaria & 0.6 & 0.8 & 1.0 \\
\hline & Poland & 1.1 & 1.1 & 0.8 \\
\hline & Romania & 0.0 & -1.3 & 1.2 \\
\hline & $\begin{array}{l}\text { Republic } \\
\text { of Belarus }\end{array}$ & 2.3 & 2.1 & 1.3 \\
\hline & Ukraine & 0.3 & -4.2 & -5.5 \\
\hline \multirow{5}{*}{$\begin{array}{l}\text { 3. Return on } \\
\text { Equity } \\
\text { (ROE), \% }\end{array}$} & Bulgaria & 5.7 & 7.2 & 7.4 \\
\hline & Poland & 12.1 & 12.3 & 9.1 \\
\hline & Romania & 0.1 & -12.5 & 11.8 \\
\hline & $\begin{array}{l}\text { Republic } \\
\text { of Belarus }\end{array}$ & 16.2 & 15.3 & 10.4 \\
\hline & Ukraine & 1.7 & -31.9 & -65.5 \\
\hline \multirow{5}{*}{$\begin{array}{c}\text { 4. Capital } \\
\text { adequacy } \\
\text { ratio (CAR), } \\
\%\end{array}$} & Bulgaria & 17.0 & 21.9 & 22.2 \\
\hline & Poland & 15.7 & 14.7 & 16.0 \\
\hline & Romania & 15.5 & 17.6 & 19.2 \\
\hline & $\begin{array}{l}\text { Republic } \\
\text { of Belarus }\end{array}$ & 15.5 & 17.4 & 18.7 \\
\hline & Ukraine & 20.6 & 26.4 & 33.0 \\
\hline
\end{tabular}

http://data.imf.org/regular.aspx?key=6094972o. Last accessed: January, 22, 2017.

During the analyzed period there is a tendency to increasing the indicators of return on equity and return on assets that means the increasing of banking effectiveness. It is the result of influence of the net income growth to $34.47 \%$ (from \$ $354.94 \mathrm{mln}$ in 2013 to $\$ 477.30 \mathrm{mln}$ in 2015) and capital growth to $3.23 \%$ (from $\$ 6.24$ bln in 2013 to $\$ 6.44$ bln in 2015). Due to the insignificant currency devaluation during the analyzed period, growth of total assets can be seen only by examining their data in national currency $(+4.48 \%)$, whereas in terms of dollars value the changes of this indicator show a tendency to decrease $17.12 \%$ (from $\$$ 59.00 bln in 2013 to $\$ 48.90$ bln in 2015). While the changes of capital adequacy ratio characterize a tendency to increase from $17.00 \%$ in 2013 to $22.18 \%$ in 2015, the risk-weighted assets decreased by $29.15 \%$ over the analyzed period, indicating the increasing of the risk assets in banking portfolios. The analysis of liquid assets to total assets ratio shows a positive dynamics of its changes (31.60\% in 2015), which is a testament of increasing of liquid funds' availability that can be used to fulfill liabilities. In Bulgaria, as in many other countries after the world crisis of 2008-2009, exists a tendency of a significant reduction of bank lending, that is proved by a significant reduction of total gross loans - to $\$ 11.88$ bln or $28.23 \%$.

\subsection{Poland's banking system characteristics}

The banking system in Poland is one of the most attractive in the Eastern Europe. Before the crisis it developed very quickly and attracted foreign investors. On the market there are foreign banks and accordingly the possibilities of accessing the international market financing. At the beginning of 2017 the system was formed by 59 banks, 20 of which are branches of banks from 10 different countries: Sweden, France, Ireland (4 branches of foreign banks), Denmark, Portugal, Luxembourg (2 branches of foreign banks), Italy, Austria, Germany, Spain (1 branch of foreign bank).

On the banking market there are also 562 cooperative banks and 47 credit unions. The number of closed banks during 2013-2015 reached 25, while only 4 new banks opened [20]. The first ten banks according to the assets (77.84\% of total assets) as well as in Bulgaria are represented mainly by the banks with foreign capital, in addition to PKO Bank Polski, Getin Noble Bank S.A. and Bank Handlowy, which have accordingly 1, 7 and 10 places (Fig. 3) and occupy $24.56 \%$ of the market.

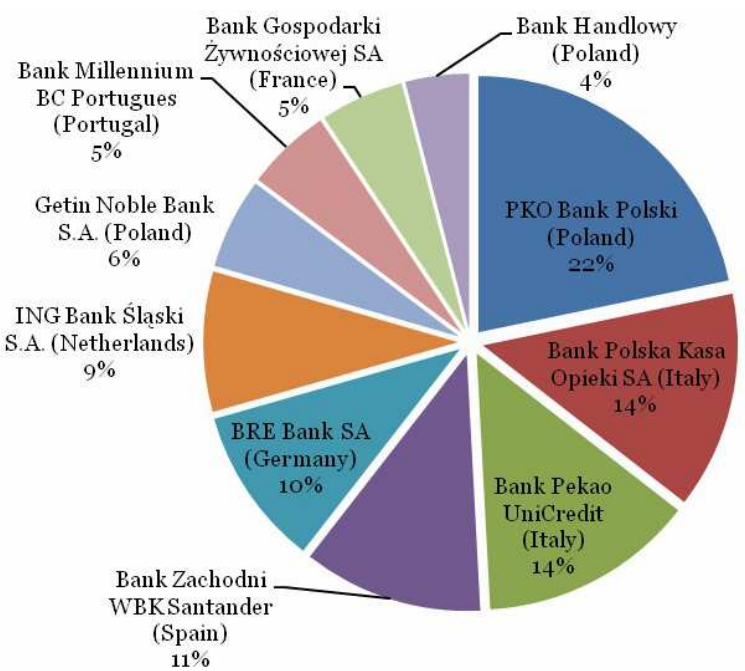

Fig. 3. The largest banks in Poland in terms of total assets (as of January 01, 2017) (source: List of Banks in Poland. Available at: https://thebanks.eu/banks-bycountry/Poland. Last accessed: January, 22, 2017). 
One of the peculiarities of the banking system in Poland is its fairly traditional model of banking. It means that banks did not invest into the complex financial instruments and therefore the main channel of crisis spreading in Poland did not act. According to the influence of the crisis on economy, as was already mentioned above, Poland is an unique country in Eastern Europe because there was not any economical recession in general and the influence on the banking sector was less significant and now the country has a stable development. According to the methodology BICRA mentioned above, Poland is included into group 5 with economic risk scored " 5 " and industry risk scored «5» [18]. Financial market development in Poland is scored 4.2 and ranked $46^{\text {th }}$ economy. Soundness of banks is scored 5.4 bringing Poland into the $49^{\text {th }}$ place, trustworthiness and confidence of financial market is scored 4.6 ( $44^{\text {th }}$ place) [19], [20].

Analyzing the main indicators of the banking system in the dynamics (Table 1), we can conclude that the situation in the banking sector is stable. Analyzing the data of indicators of return on assets and return on equity, there is a tendency to decreasing of their values. It is the result of net income reduction to $34.84 \%$ (from $\$ 5.03$ bln in 2013 to $\$ 3.28$ bln in 2015). In the part of assets and capital there is a small growth when examining their volumes in the national currency (13.18\% and $7.86 \%$ respectively), but considering the exchange rate growth to $29.57 \%$ in dollars equivalent, these indicators are decreasing to $12.65 \%$ and $16.76 \%$. Capital adequacy ratio rose from $15.70 \%$ in 2013 to $16.00 \%$ in 2015 due to contemporaneous changes in total regulatory capital $(+8.85 \%)$ and risk-weighted assets $(+6.88 \%)$ in the national currency. The analysis of liquid assets to total assets ratio indicates negative dynamics of its changes $(21.40 \%$ in $2013,20.10 \%$ in 2015), pointing at the decrease of available liquid funds for covering liabilities. It's caused by the increasing of total assets in the national currency $(+13.18 \%)$ mainly due to the total gross loans growth $(+13.06 \%)$ at contemporaneous insignificant growth of liquid assets (+6.85\%). It should be noted that Poland did not stop the growth of credit portfolios, as it was typical for most countries in the post-crisis period, but rather reduced the rate of growth.

\subsection{Romania's banking system characteristics}

Romania's banking sector is a typical example for countries of Eastern Europe. After shifting to a market economy, most of these countries created the premises for foreign banks to dominate their banking sector. About $90.2 \%$ of bank assets in Romania are held by institutions with foreign capital. The banks with Austrian capital have a market share of $33.3 \%$, followed by the banks with French capital (13.5\% market share) and those with Greek capital (10.6\% market share). The group of the banks with assets of over $5 \%$ from the total volume of banking sector assets held a weight of $71.3 \%$ at the end of 2015, up by $4.3 \%$ compared to December 2014, while the group of middle-sized banks (with assets between $1 \%$ and 5\%) held $22.4 \%$ (down by $3.9 \%$ compared to December 2014), and the banks with assets under $1 \%$ had a weight of $6.3 \%$, according to the National Bank of Romania Report [21]. At the beginning of 2017 the system includes 39 banks, 8 of which are branches of foreign banks of Cyprus, Belgium, Bulgaria, France, Ireland, Italy, Netherlands and Spain. During the analyzed period there were closed 5 banks and were opened 3 [22]. In contrast to this situation, the first ten banks by assets $(81.07 \%$ of total assets) are presented by the banks with Romanian (41.30\%) and foreign (39.77\%) capital (Fig. 4).

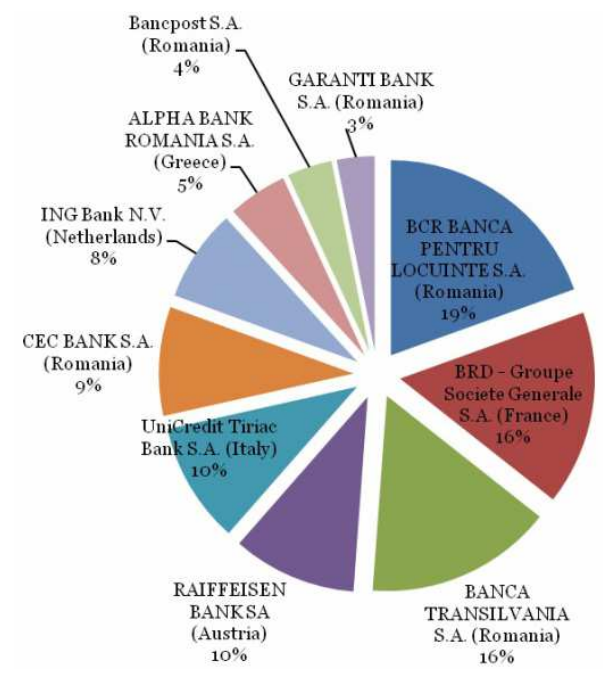

Fig. 4. The largest banks in Romania in terms of total assets (as of January 01, 2017) (source: Topul bancilor dupa active in 2015. Available at: http://bancherul.ro/topulbancilor-dupa-active-in-2015--16420. Last accessed: January, 22, 2017).

The Romanian banking sector has demonstrated its structural stability being among the few banking sectors from the European Union which did not need the state's support during the crisis. Nevertheless Romania in comparison to the countries of Central Europe has a significantly less developed banking sector. This is proved by the main economical indicators such as the loans and deposits volume to GDP ratio, as well as the financial services' level extension.

The outlook on the Romanian banking sector depends upon the harmony of the domestic legal acts in banking matters with the principles imposed by the European directives on the uniform regulating of the European banking sector. For current investors, the coherence of the legislative act and the predictability of the business environment are essential and investors are somewhat obliged to migrate to markets that provide more stability from all points of view [21]. Financial market development in Romania is scored 3.7 and ranked as the $86^{\text {th }}$ economy. Soundness of banks is scored 4.4 bringing Romania into the $90^{\text {th }}$ place, and 
trustworthiness and confidence of financial market is scored 4.6 (43 ${ }^{\text {rd }}$ place) [19], [22]. According to the market survey called «Financial Education» conducted by GfK Romania, in May 2016, trust in banks went up from $33.00 \%$ to $40.00 \%$, in the case of the respondents who had high trust in banks [21].

Let's study the following indicators of the Romanian banking system in dynamics (Table 1). According to the following values of return on assets and return on equity in Table 3, we can say that the bank's condition got much better in 2015 compared to the previous years. Negative values of both indicators in 2014 were caused by unprofitability of banks. The banking system showed a slight growth of total assets $(+2.08 \%$ in the national currency). Net income was much higher in 2015 compared to 2013 (in 92.12 times). Another positive change is the reduction of the riskweighted assets volume in 2015 compared to $2013 \quad$ (0.18\%) with contemporaneous increasing of total regulatory capital $(+23.75 \%)$, which ultimately affected on the capital adequacy ratio. Liquid asset ratio in 2015 is decreased comparing to 2013 due to the liquid assets decreasing in the national currency to $19.36 \%$. Concerning the lending level, with the coming of crisis to Romania it has significantly slowed down. During the analyzed period there are not almost any significant changes observed in total gross loans: $-3.10 \%$ in 2014 comparing to 2013 and $+2.93 \%$ in 2015 comparing to 2014.

\subsection{The Republic of Belarus banking system's characteristics}

Due to Belarus not being a market economy, its banking system is basically formed by state-owned banks and as of 01.04.2016 included 26 banks and 5 charter's capital which are formed by resources of state and companies, based on the state ownership. The state's share in bank's charter capital in general reaches up to $81.65 \%$ [23]. The foreign capital in the banking system of the Republic of Belarus is coming from such countries as: Russia, Austria, Cyprus, the UK, Ukraine, the Netherlands, Luxembourg, Kazakhstan, Switzerland, Iran, Latvia, Ireland, USA, Czech Republic. On the territory of the Republic of Belarus functions a range of foreign branches of banks, including Commerzbank AG (Germany), SNORAS (Lithuania), Rietumu Banka (Latvia), Trasta komercbanka (Latvia), UniCredit Bank (Russia). Belarusian banks also have their representatives abroad: Belagroprombank has a representative office in Italy and ASB Belarusbank - in China [24]. The first ten banks according to the assets (94.05\% of total assets) are represented by banks with Belarusian, Russian and Austrian capital (Fig. 5). Being under governmental direct administration, the banking sector of the Republic of Belarus has an important role in economy stimulation. Particular importance has the banking lending within the governmental programs: the state banks lend money at low interest rates to entities that are considered more important by the government opinion (mostly to agricultural and construction companies and to the people who's ready to get cheap mortgage). According to the BICRA methodology, the Republic of Belarus is included into the group 10 with economic risk scored «10» and industry risk scored «10» [18].

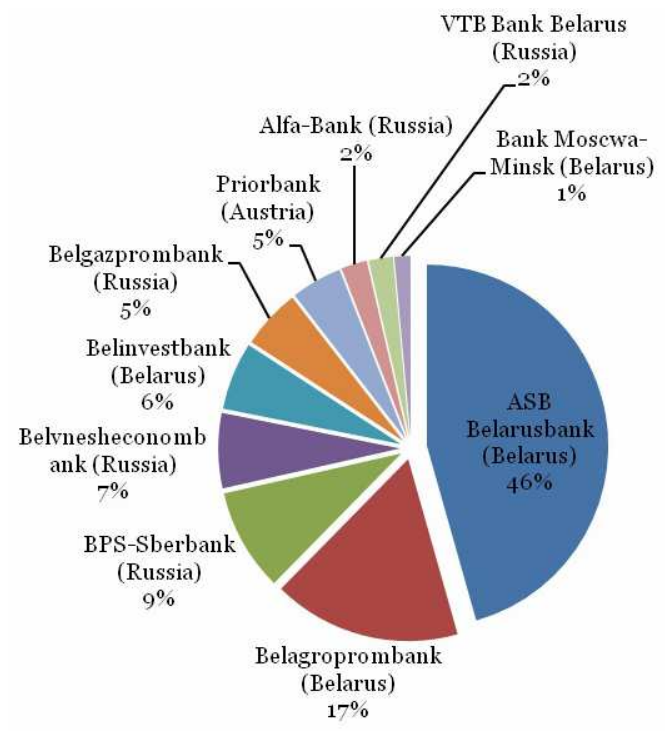

Fig. 5. The largest banks in Republic of Belarus in terms of total assets (as of October 01, 2016) (source: The official banks rating. The assets, liabilities, equity. Available at: $\quad$ http://infobank.by/oficialjnyj-rejtingbankov81/?pu= True \&qs=\%2F1574\%2Fdefault.asp $x \& q w=\% 25$ do\%259e\%25 do\%259o\%25do\% $259 \mathrm{e} \% 20 \% 25 \mathrm{do} \% 2591 \% 25 \mathrm{do} \% 25 \mathrm{bo} \% 25 \mathrm{do}$ $\% 25 b d \% 25 d o \% 25 b a \% 20 \% 25 d o \% 2591 \% 25$ do\% $25 b 5 \% 25$ do\% $25 \mathrm{bb} \% 25 \mathrm{do} \% 2592 \% 25 \mathrm{do} \% 25 a d \% 25 d o$. Last accessed: January, 22, 2017).

The indicators of banking system of the Republic of Belarus shown in Table 1. The return on assets and return on equity ratios, presented in Table 4, point towards a decline in the dynamics of the banking system. This is connected to a significant growth of total assets in the national currency $(+61.21 \%$ in 2015 comparing with 2013). At the same time there is an increase in the liquid assets in the national currency to $36.85 \%$ during the analyzed period. The banks also perform an active capitalization that led to the increasing of capital in 2016 to $41.12 \%$ comparing with 2013. The volume of given loans during the analyzed period increased 1.47 times. The negative side is the increasing of risk-weighted assets that indicates the increasing of low quality classified loans into the credit portfolio of banks. The analyzed period is characterized by a great devaluation of the Belarusian ruble ( 1,96 times) and the slowdown of economic growth. Considering the foreign exchange risk and the increasing disbalance of some assets and liabilities in foreign currency, banks face with the problems of decreasing of the regulatory capital, the ratios for which are set in Euros. Decreasing of the size of regulatory capital in Euros equivalent leads to decreasing of 
volume of loans in foreign currency that the bank can give without breaking the capital adequacy ratio and ratios connected with the credit risk. In the conditions of expectation of non-performing loan's growth in the banking sector of Belarus considering the downfall of financial state of borrowers and tightening the lending terms, insufficient capitalization of the banks may become critical for the bank solvency. Besides, capital insufficiency affects negatively the positioning of the Belarusian banks in the international ranking, because the capital is taken into account by foreign banks when giving loans, as well as by rating agencies during preparation of the ratings.

\subsection{Ukraine's banking system characteristics}

The banking system of Ukraine is represented by 111 banking institutions, including 43 banks with foreign capital. In the first half of 2016 the ownership structure of assets of the Ukraine's banking system is presented in this way: private banks with Ukrainian capital were around $35 \%$, banks belonging to foreign banking groups represented 34\%, and state-owned banks were $31 \%$ [25]. The first ten banks according to the assets (73.08\% of total assets) were represented by the banks from the following countries with the corresponding shares in the total assets of the banking system: Ukraine (55.21\%), Russia (10.66\%), Austria (3.98\%), France (3.22\%) (Fig. 6).

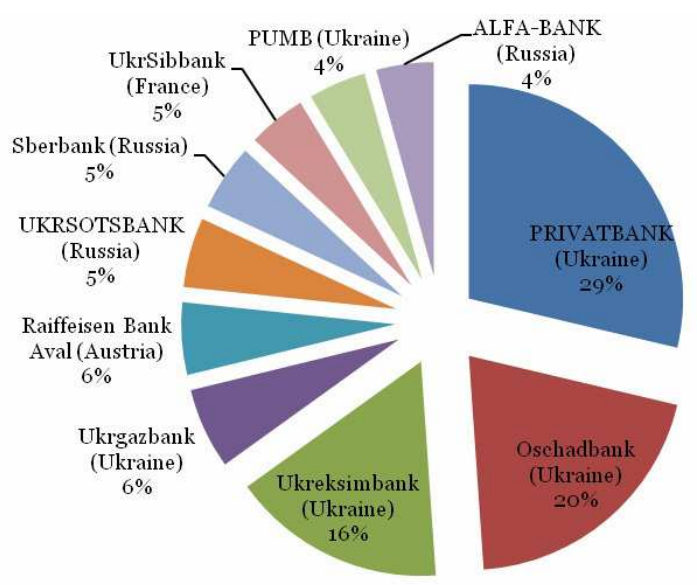

Fig. 6. The largest banks in Ukraine in terms of total assets (as of October 01, 2016) (source: National Bank of Ukraine. The official website . Banking system indicators. Available at: https://bank.gov.ua/control/uk/publish/ article?art_id=34661442\&cat_id=34798593. Last accessed: January, 22, 2017).

According to the BICRA methodology, Ukraine has exactly the same position as Republic of Belarus [18]. Financial market development in Ukraine is scored 3.0 and ranked as the $130^{\text {th }}$ economy. Soundness of banks is scored 2.1 bringing Ukraine into the $138^{\text {th }}$ place [19].

Analyzing the data in Table 1, we may conclude that there is a significant decline of the banking system of Ukraine. The return on assets, return on equity and liquid asset ratios have a negative dynamic due to the unprofitability of the whole system, that in 2015 was \$ $3.04 \mathrm{bln}$. The capital in the national currency during the analyzed period decreased by $37.49 \%$. The banks' total assets in national currency have also increased in 2015 against 2013 by $10.16 \%$ as have total gross loans $(+11.11 \%)$ and liquid assets $(+58.68 \%)$. The basic factor of such oscillation of banking system's assets is the dynamics of exchange rates, because the large part of credit portfolios are formed by the loans in foreign currency, and the exchange rate in 2015 increased 3 times compared to 2013. Generally the credit activity of banking institutions continues to be not high, due to the limited number of reliable borrowers, high level of uncertainty about the future economic development and high costs of loans resources. Ukraine's banking sector is characterized by low quality of the credit portfolio, the capitalization downfall, limited access to resources on the international market, reduction of population's trust, lack of transparency during the refinancing to the commercial banks and lack of liquidity. Since 2014 the Ukrainian banking sector has been recovering after closing the weak banks. However, there is paradox here. While between 2014 and 201680 banking institutions were closed for owning a little less than half the funds to back the loans, many other banks in the same situation continue to receive significant refinancing from the central bank using the delays in the capitalization plan and there are no sanctions for non having the appropriate banking indicators [26]. According to the results of Ukrainian banks sustainability ranking, the top ten banks with high level of sustainability are CreditAgricole (France), Reiffeisen Bank Aval (Austria), ProCredit Bank (Germany), ING Bank Ukraine (Netherland), Citibank (the USA), UkrSibbank (France), Pravex-Bank (Italy), CredoBank (Poland), UniCredit Bank (Russia), Alfa-Bank (Russia) [27]. These foreign banks managed not only to survive during the crisis with minimal losses for their balance and reputation, but also, through support from headquarters, continue to keep a strategic course of their market positions in Ukraine. One of the main factors on which depends the future of banks is the ability to fulfill the requirements of the National Bank of Ukraine about the additional capitalization. Banks that have no possibility to implement the required amount of the additional capitalization would be forced to unite with the other banks or to leave the market. In addition an important issue for the banks is the ownership structure legalization [28]. The need for active participation of banks in the investment process follows the correlation between the banking system and the economy. On the one hand, banks are interested in a stable economic environment that is essential for their operation, and on the other hand, the stability of economic development widely depends on the financial stability and effective functioning of the banking system. The important role of the banking sector in the 
economic development of the country is determined by the ability to establish a channel for the uninterrupted transfer of temporarily free financial funds to the real sector of the economy that requires substantial investments for the modernization of fixed assets, to overcome the crisis phenomena and enter the path of sustainable economic growth. Researching the banking sector participation in the economy of a country, it is appropriate to analyze such indicators as total assets to GDP, total gross loans to GDP and total liabilities to GDP (Table 2).

Table 2. Indicators of banking system's role in economy.

\begin{tabular}{|c|c|c|c|c|}
\hline Indicators & Countries & 01.01.14 & 01.01.15 & 01.01.16 \\
\hline \multirow{5}{*}{$\begin{array}{l}\text { 1. Total } \\
\text { assets to } \\
\text { GDP, \% }\end{array}$} & Bulgaria & 105.82 & 91.99 & 97.41 \\
\hline & Poland & 87.99 & 77.46 & 85.16 \\
\hline & Romania & 56.72 & 47.93 & 48.96 \\
\hline & $\begin{array}{l}\text { Republic } \\
\text { of Belarus }\end{array}$ & 50.39 & 47.38 & 55.19 \\
\hline & Ukraine & 81.57 & 61.96 & 60.52 \\
\hline \multirow{5}{*}{$\begin{array}{l}\text { 2. Total gross } \\
\text { loans to } \\
\text { GDP, } \%\end{array}$} & Bulgaria & 75.46 & 63.68 & 60.15 \\
\hline & Poland & 68.64 & 60.90 & 66.61 \\
\hline & Romania & 47.42 & 38.98 & 39.99 \\
\hline & $\begin{array}{l}\text { Republic } \\
\text { of Belarus }\end{array}$ & 39.71 & 37.57 & 39.55 \\
\hline & Ukraine & 64.29 & 51.08 & 48.11 \\
\hline \multirow{5}{*}{$\begin{array}{l}\text { 3. Total } \\
\text { liabilities to } \\
\text { GDP, } \%\end{array}$} & Bulgaria & 94.19 & 81.35 & 77.09 \\
\hline & Poland & 78.36 & 70.64 & 76.18 \\
\hline & Romania & 65.41 & 55.06 & 56.12 \\
\hline & $\begin{array}{l}\text { Republic } \\
\text { of Belarus }\end{array}$ & 46.92 & 44.68 & 52.65 \\
\hline & Ukraine & 73.89 & 55.27 & 53.00 \\
\hline
\end{tabular}

Source: Bulgaria GDP. Available at: http://www.tradingeconomics. com/bulgaria/gdp. Last accessed: January, 22, 2017:

Poland GDP. Available at: http://www.tradingeconomics.com/ poland/gdp. Last accessed: January, 22, 2017;

Romania GDP. Available at: http://www.tradingeconomics.com/ romania/gdp. Last accessed: January, 22, 2017;

Belarus GDP. Available at: http://www.tradingeconomics.com/ belarus/gdp. Last accessed: January, 22, 2017;

Ukraine GDP. Available at: http://www.tradingeconomics.com /ukraine/gdp. Last accessed: January, 22, 2017;

IMF Data. Financial Soundness Indicators. Available at: http://data.imf.org/regular.aspx?key=60949720 Last accessed: January, 22, 2017; IMF Data. Exchange Rates. Available at: http://data.imf.org/regular.aspx?key $=60998108$. Last accessed: January, 22, 2017.

Total gross assets to GDP ratio allows to identify how well do the economic agents satisfy their financial needs. Analysis of mentioned indicators in Table 6 shows the high level of covering the economies of Bulgaria and Poland by banking assets in contrast to Romania, Republic of Belarus and Ukraine. The value of this ratio increased only for the Republic of Belarus $(+4.8 \%)$. The most in need of support of banks remains the economy of Ukraine (-21.05\%).

Within the structure of banking sectors' assets of the analyzed countries, loans dominate. For all analyzed countries this indicator has a negative tendency, with the most reduced lending levels to the economies of Bulgaria (-15.31\%) and Ukraine (-16.18\%) that forces enterprises to use their own financial funds.

Table 3. Correlation between bank investments and GDP tendencies.

\begin{tabular}{|c|c|c|c|}
\hline Country & Indicator & $\begin{array}{l}\text { Growth/decline } \\
2014 / 2013(\%)\end{array}$ & $\begin{array}{l}\text { Growth/decline } \\
\text { 2015/2014 (\%) }\end{array}$ \\
\hline \multirow{3}{*}{ Bulgaria } & $\begin{array}{l}\text { 1. Total gross } \\
\text { loans }\end{array}$ & -14.14 & -16.41 \\
\hline & $\begin{array}{l}\text { 2. Total } \\
\text { liabilities }\end{array}$ & -12.13 & -16.14 \\
\hline & 3. GDP & 1.74 & -11.51 \\
\hline \multirow{3}{*}{ Poland } & $\begin{array}{l}\text { 1. Total gross } \\
\text { loans }\end{array}$ & -8.09 & -4.71 \\
\hline & $\begin{array}{l}\text { 2. Total } \\
\text { liabilities }\end{array}$ & -6.60 & -6.06 \\
\hline & 3. GDP & 3.60 & -12.88 \\
\hline \multirow{3}{*}{ Romania } & $\begin{array}{l}\text { 1. Total gross } \\
\text { loans }\end{array}$ & -14.39 & -8.48 \\
\hline & $\begin{array}{l}\text { 2. Total } \\
\text { liabilities }\end{array}$ & -12.34 & -9.08 \\
\hline & 3. GDP & 4.15 & -10.80 \\
\hline \multirow{3}{*}{$\begin{array}{l}\text { Republic } \\
\text { of } \\
\text { Belarus }\end{array}$} & $\begin{array}{l}\text { 1. Total gross } \\
\text { loans }\end{array}$ & -1.49 & -24.46 \\
\hline & $\begin{array}{l}\text { 2. Total } \\
\text { liabilities }\end{array}$ & -0.85 & -15.45 \\
\hline & 3. GDP & 4.10 & -28.24 \\
\hline \multirow{3}{*}{ Ukraine } & $\begin{array}{l}\text { 1. Total gross } \\
\text { loans }\end{array}$ & -42.13 & -36.07 \\
\hline & $\begin{array}{l}\text { 2. Total } \\
\text { liabilities }\end{array}$ & -45.53 & -34.91 \\
\hline & 3. GDP & -27.17 & -32.12 \\
\hline
\end{tabular}

Source: Bulgaria GDP. Available at: http://www.tradingeconomics. com/bulgaria/gdp. Last accessed: January, 22, 2017;

Poland GDP. Available at: http://www.tradingeconomics.com/Poland /gdp. Last accessed: January, 22, 2017;

Romania GDP. Available at: http://www.tradingeconomics.com/ romania/gdp. Last accessed: January, 22, 2017;

Belarus GDP. Available at: http://www.tradingeconomics.com/belarus /gdp. Last accessed: January, 22, 2017;

Ukraine GDP. Available at: http://www.tradingeconomics.com/ukraine /gdp. Last accessed: January, 22, 2017;

IMF Data. Financial Soundness Indicators. Available at: http://data imf.org/regular.aspx?key=60949720. Last accessed: January, 22, 2017; IMF Data. Exchange Rates. Available at: http://data.imf.org/ regular. aspx?key=60998108. Last accessed: January, 22, 2017.

The main sources of the financial resources of banks become the funds of households and firms. The values of total liabilities to GDP ratios show negative tendency similar to the total gross loans to GDP ratios for all the countries except for the Republic of Belarus the ratio of which increased by $5.73 \%$. In general, if we compare the total loans and liabilities to GDP ratios, then their changes over the analyzed period are as follows: Bulgaria: $-15.31 \%$ and $-17.10 \%$; Poland: $-2.03 \%$ and 2.18\%; Romania: $-7.43 \%$ and $-9.29 \%$; Republic of Belarus: $-0.16 \%$ and-5.73\%; Ukraine: $-16.18 \%$ and $-20.89 \%$. 
The correlation between the real sector of the economy and its bank financing is also confirmed by the data in Table 3: the trends in lending into the economy depend on trends of development changes of the economy. For example, in Bulgaria the reduction of loan portfolios for 2015 was $16.41 \%$ and there is a corresponding reduction in GDP by $11.51 \%$. Similar correlation is observed in Romania $(-4,71 \%$ and 12.88\%), Republic of Belarus (-24.46\% and -28.24\%), Ukraine (-36.07\% and $-32.12 \%)$. A smaller correlation is observed in Poland's economy (-4.71\% and $-8.48 \%$ ) that can be caused by additional investment in the economy that is different from banking sources. The correlation between the formation of banks' financial resources for its next investment into the economy by deposits of households and firms is noticed if we analyze the mutual tendencies of changes in total gross loans and total liabilities: in 2015 accordingly for Bulgaria 16.41\%/-16.14\%, Poland -4.71\%/-6.06\%Romania 8.48\%/-9.08\%, Republic of Belarus -24.46\%/15.45\%, Ukraine $-36.07 \% /-34.91 \%$.

It is also important to note that, in addition to banking investments, great importance for the development of economies have EU's target investments. For example, among the analyzed countries, Poland has a significant support from the EU. Poland and Ukraine are both post-socialist countries that had approximately the same starting positions at the beginning of the transition period, similar economic structure and a polarized political system. However, Poland that began to follow the course of European integration much earlier achieved greater economic success compared to Ukraine which, for a long time, had a more ambiguous orientation, towards both west and east. Since Poland's accession to the EU, the country's economic growth has significantly accelerated: although Poland's membership contribution amounted $€_{30} \mathrm{bln}$, in the period betwee 2004 and 2013, Poland received $€ 92.4$ bln from the EU budget within the operational programs - the equalization policy and the support of agriculture [29], [30]. As of today, the EU provides subsidies in according to five operational programs in fields of digital, smart growth, technical assistance, infrastructure and environment and 16 regional operational programs [31]. At the same time, the direct investments from the EU countries to Ukraine decreased significantly since 2014 (2013 - \$41.10 bln, 2016 - $\$ 26.10$ bln) caused by fluctuations in the political environment of Ukraine [32].

Foreign investments from the EU have a favorable effect for Romania: for ten years of its membership in the EU Romania received about $€ 33$ bln and so tens of thousands of jobs were created. The country's nominal GDP grew from $€ 100$ bln in 2007 to about $€ 170$ bln at the end of 2016 (+70\%) [33]. The EU gives subsidies to Romania according to four operational programs in the fields of competitiveness, infrastructure, small and medium-sized enterprises initiative, technical assistance and one regional operational program [31]. According to the EU's operational programs, $€ 7.6$ bln should be received by Bulgaria between 2014 and 2020 for job creation, innovation development, infrastructure projects, education and social structure [34]. Currently there are six operational programs in the fields of science and education for smart growth, environment, innovations and competitiveness, regional growth, transport infrastructure [31]. The inflow of foreign direct investments to Belarus as of 01.01.2017 consists of $53.8 \%$ of the EU countries investments and of $33.0 \%$ of the Eurasian Economic Union investments. At the same time one of the key fields in cooperation with the EU is the mobilization of foreign investments to the Belarusian economy, first of all, in the production of high technology and high-tech goods, high-quality agricultural products, introduction of alternative energy sources and increasing energy efficiency, and development of transit potential [35], [36].

\section{CONCLUSION}

As a result of the analysis we can draw the following conclusions about the economies and banking systems of analyzed Eastern European countries:

1). Despite the relatively close geographical location of the analyzed countries, they have different types of economy (market and transition), different levels of development according to the basic socioeconomic indicators (GDP and HDI), different possibilities to access to both - banking resources (depending on the banking sector development) and foreign investments (considering the membership in the EU).

2). In the banking sectors of the analyzed countries there is the presence of high share of foreign capital, which Thus, in case of economic decline in the Euro zone such dependence on external financing can lead to a high risk of asset withdrawal from the country and as a result to credit crunch and non-fulfillment of capital adequacy standards. At the same time, small number of banks prevail in the market: such model of banking system can be geographically diversified, it means that it is full of banks from different countries and also with the national banks domination.

3). The regulatory capital of banks increases slowly which does not allow to strengthen the market positions and fit the standards of the Basel committee in terms of structure, components, quality and stability of the capital base. The insufficient level of financial safety, compared with the Western European banks are confirmed by the Global Finance ranking results [37]. The TOP-50 includes only three Eastern European banks: Komerční banka (rank 44) and Česká spořitelna (rank 48) from Czech Republic, and ING Bank Śląski (rank 50) from Poland. Banks are characterized also by 
the slow credit portfolios increasing time and by lowquality and overdue loans. Worsening of this situation might be in the case of weakening of borrowers' financial condition and the country's economy condition in general that is approved by the significant devaluation of the national currency.

4). There is a close correlation between the development of the real sector of the economy and banking investments. The role of the banking sector has grown significantly for Poland and Bulgaria that can be confirmed with high values of total gross loans to GDP ratios while for the Republic of Belarus and Ukraine the lending is significantly reduced.Foreign direct investments from the EU play an important role in the economic development of the CEE countries under analysis.

Based on this, the relationships with the parental structures in Central and Western Europe would become the determining stability factor of the banks and real sector development in the future .

\section{REFERENCES}

[1]*** (2016), Country comparison: GDP per capita (PPP). Central Intelligence Agency. Available at: https://www.cia.gov/library/publications/the-worldfactbook/rankorder/2004rank.html.

[2] *** (2016), Global 2016 Human Development Report. Unite Nation Development Programme. Available at: http://www.hdr.undp.org/sites/default/ files/2016_human_development_report.pdf.

[3] *** (2016), The World Factbook. Bulgaria. Central Intelligence Agency. Available at: https://www.cia.gov /library/publications/the-world-factbook/geos/bu.ht $\mathrm{ml}$.

[4] *** (2016), The World Factbook. Poland. Central Intelligence Agency. Available at: https://www.cia.gov/ library/publications/the-world-factbook/geos/pl.html. [5] *** (2016), The World Factbook. Romania. Central Intelligence Agency. Available at: https://www.cia.gov/ library/publications/the-world-factbook/geos/ro.html. [6] *** (2016), The World Factbook. Ukraine. Central Intelligence Agency. Available at: https://www.cia.gov/ library/publications/the-world-factbook/geos/up.html. [7] *** (2016), The World Factbook. Belarus. Central Intelligence Agency. Available at: https://www.cia.gov/ library/publications/the-world-factbook/geos/bo.html.

[8] Shenin, R. (2010), Bankovskiye sistemy stran mira [The Banking Systems of the World], KNORUS, Russia, $400 \mathrm{p}$.

[9] Åslund, A. (2013), How the Central and Eastern European Banking System Managed the Financial Crisis, Peterson Institute for International Economics, the USA. Available at: https://piie.com/blogs/realtimeeconomic-issues-watch/how-central-and-easterneuropean-banking-system-managed.

[10] Barjaktarović, L., Paunović, M., Ječmenica, D. (2013), Development of the Banking Sector in CEE
Countries - Comparative Analysis, Journal of Central Banking Theory and Practice, vol. 2, Montenegro, pp. 93-114. Available at: http://www.cbcg.me/repec/cbk/ journl /vol2no2-6.pdf.

[11] Kasiyan, E. (2012), Osobennosti razvitiya bankouskogo sektora stran Tsentral'noy $i$ Vostochnoy Yevropy $v$ perekhodnyy period [Features of the Banking Sector Development in Central and Eastern Europe in Transition], In: Business-Info, №10, Research Center of Industrial Problems of Development of NAS of Ukraine, Ukraine, pp. 221-226.

[12] Cevik, N., Dibooglu, S., Kutan, A. (2016), Real and Financial Sector Studies in Central and Eastern Europe: A Review, Czech Journal of Economics and Finance, 66, no. 1, Czech Republic, pp. 2-31. Available at: http://journal.fsv.cuni.cz/storage/1346_cevik.pdf.

[13] Rym, A. (2016), Banking Business Models Monitor 2015 Europe, The International Research Center on Cooperative Finance, Canada, 125 p. Available at: https://papers.ssrn.com/sol3/papers.cfm?abstract_id=2 784334. Last accessed: January, 22, 2017.

[14] Nurboja, B., Košak, M. (2016), Banking efficiency in South East Europe: Evidence for financial crises and the gap between new EU members and candidate countries, Economic Systems, Germany. Available at: http://www.sciencedirect.com/science /article/pii/So939362516301005.

[15] Poloucek, S. (2004), Reforming the Financial Sector in Central European Countries, Palgrave Macmillan UK, the United Kingdom, $221 \mathrm{p}$.

[16] Hnativ, E. (2016), Zarubezhnyy opyt razvitiya rynka bankovskikh uslug [Foreign Experience of Banking Market's Development], Theses of VII international scientific-practical conference "Banking system: stability and development prospects", 4-5 of April 2016, KK Shebeko, Polessky State University, the Republic of Belarus, pp. 22-26. Available at: http://rep.polessu.by/bitstream/112/10228/1/7.pdf.

[17] *** (2017), Economy and Banking Sector of Bulgaria. TheBanks.eu. Available at: https://thebanks. eu/countries/Bulgaria. Last accessed: January, 22, 2017.

[18] *** (2015), Banking Industry Country Risk Assessment Update: December 2015, S\&P Global Market Intelligence, Global credit portal. Available at: https://www.globalcreditportal.com/ratingsdirect/rend erArticle.do ?articleId=1552435\&SctArtId=360429\&fro m=CM\&nsl_code=LIME\&sourceObjectId $=9451072 \&$ so urceRevId=1\&fee_ind=N\&exp_date $=20251215$ 01:45:19. Last accessed: January, 22, 2017. [19] *** (2016), The Global Competitiveness Report 2016-2017, Klaus Schwab, World Economic Forum. Available at: http://www3.weforum.org/docs/GCR 2016-2017/o5FullReport/TheGlobalCompetitiveness

Report2016-2017_FINAL.pdf. Last accessed: January, 22, 2017.

[20] *** (2017), Economy and Banking Sector of Poland. Available at: https://thebanks.eu/countries/ Poland. Last accessed: January, 22, 2017. 
[21] *** (2016), The banking sector of Romania, Romanian Banking Association. Available at: http://www.arb.ro/en/romanian-banking-sysoo74em/ romanian-banking-system-2. Last accessed: January, $22,2017$.

[22] *** (2017), Economy and Banking Sector of Romania. TheBanks.eu. Available at: https://thebanks.eu/countries/Romania. Last accessed: January, 22, 2017.

[23] *** (2016), Bankovskij sektor Respubliki Belarus na 01.04.2016 [The banking sector of the Republic of Belarus as of 04.01.2016], General Directoction of the Banking Supervision of the National Bank of the Republic of Belarus. Available at: https://www.nbrb.by/publications/banksector/bs_201 60401.pdf. Last accessed: January, 22, 2017.

[24] *** (2016), Finansovaja sistema Belarusi [Financial System of Belarus], Belarus. Facts. Available at:http://belarusfacts.by/ru/belarus/economy_busines s/key_economic/banks_and_finance. Last accessed: January, 22, 2017.

[25] *** (2016), Analitychnyy ohlyad bankivs'koyi systemy Ukrayiny za I pivrichchya 2016 r. [Analytical review of the banking system of Ukraine for the first half of 2016], Rurik National Rating Agency. Available at: http://rurik.com.ua/documents/research/bank _system_2_kv_2016.pdf. Last accessed: January, 22, 2017.

[26] Efimenko, T. (2016), Yak ozdorovyty bankius'kyy sektor Ukrayiny [How to improve the banking sector of Ukraine], Forbes Ukraine, Ukraine. Available at: http://forbes.net.ua/ua/opinions/ 1424069-yak-ozdoroviti-bankivskij-sektor-ukrayini.

Last accessed: January, 22, 2017.

[27] Korniliuk, R. (2016), Reytynh zhyttyezdatnosti ukrayins'kykh bankiv-2016 [Rating of the viability of Ukrainian Banks 2016], Forbes Ukraine, Ukraine. Available at: http://forbes.net.ua/ua/business/1421401 -rejting-zhittezdatnosti-ukrayinskih-bankiv-2016. Last accessed: January, 22, 2017.

[28]** (2016), Styslyy ohlyad bankivs'koyi systemy Ukrayiny za 1 kvartal 2016 roku [A brief overview of the banking system of Ukraine for the 1st quarter 2016], Center for Economic Research and Forecasting "Financial pulse". Available at: http://finpuls.com /ua/banking/reviews/news/Stisliy-oglyad-bankvskosistemi-Ukrani-za-1-kvartal-2016-roku.htm. Last accessed: January, 22, 2017.

[29] Kudryavtseva, I. (2014), Za 10 let $v$ ES ekonomika Pol'shi dostigla khoroshikh rezul'tatov [For
10 years in the EU Poland's economy has achieved good results], Radio Polsha. Available at: http://www. radiopolsha.pl/6/138/Artykul/169687.

[30] Moldovan, A. (2013), Integratsiya v ES: opyt Pol'shi i vyzovy dlya Ukrainy [Integration into the EU: the experience of Poland and challenges for Ukraine], ZN.UA. Available at: https://gazeta.zn.ua/macrolevel /integraciya-v-es-opyt-polshi-i-vyzovy-dlya-ukrainy_.html.

[31]*** (2017), Programmes. European Commission. Regional policy. Available at: http://ec.europa.eu /regional_policy/en/atlas/programmes.

[32] *** (2017), Pryami investitsii $z$ krain ES $v$ ekonomitsi Ukraini za 2010-2016 roki [Direct investments in the economy of Ukraine from the EU countries 2010-2016], Goverment statistics service of Ukraine. Available online at: http://www.ukrstat.gov.ua/operativ/operativ2016/zd/i ves/ives_u/iveso716_u.htm.

[33] Stefan, A. (2017), Rumyniya $v$ ES: blestyashchiy period modernizatsii $i$ razvitiya [Romania in the EU: brilliant period of modernization and development], Ziarul de garda. Available at: http://www.zdg. $\mathrm{md} / \mathrm{ru} / \mathrm{p} \mathrm{p}=8726$.

[34] *** (2015), Bolgariya osvoila boleye $75 \%$ fondov ES [Bulgaria has absorbed more than $75 \%$ of EU funds], Novinite.ru. Available at: http://www.novinite.ru /articles/16773 /Болгария+находится+в+одной+

группе+с+Германией+по+освоению+средств+из+ф ондов+ЕC.

[35] *** (2017), Investitsii $i$ inostrannyye predstavitel'stva [Investments and foreign representations], Ministry of Foreign Affairs of the Republic of Belarus. Available at: http://mfa.gov.by/ investments. Last accessed: June, 01, 2017.

[36] ${ }^{* * *}$ (2015), Belarus' $i$ strany Evropy [Belarus and European countries], Ministry of Foreign Affairs of the Republic of Belarus. Available at: http://mfa.gov.by /bilateral/europe.

[37] *** (2016), The 5o Safest European Banks 2016, Press Release, Global Finance Global Finance. Available at: https://www.gfmag.com/media/pressreleases/press-release-50-safest-european-banks-2016. Last accessed: January, 22, 2017.

[38] Cseh, M., Rozanski, A., Nemeskeri, Z., Krisztian, B. (2015), HRD in Hungary and Poland. In, R.F. Poell, T.S. Rocco \& G.L. Roth (Eds. ), The Routledge Companion to Human Resource Development (pp. 492-504). New York: Routledge 